Ege Journal of Medicine/Ege Tıp Dergisi 2018;57(4):247-249

\title{
Hashimoto's encephalopathy: Report of two cases
}

\section{Hashimoto ensefalopatisi: İki olgu sunumu}

\author{
Zerrin Yıldııım ${ }^{1} \quad$ Muazzez Gökçen Karahan ${ }^{2} \quad$ Yavuz Altunkaynak ${ }^{2}$ \\ Alper Döventaş ${ }^{3} \quad$ Sevim Baybaş ${ }^{2}$ \\ ${ }^{1}$ Bağcılar Training and Research Hospital, Clinic of Neurology, İstanbul, Turkey \\ ${ }^{2}$ Bakırköy Prof Dr. Mazhar Osman Mental and Neurological Disorders Education and Research \\ Hospital, Clinic of Neurology, İstanbul, Turkey \\ ${ }^{3}$ İstanbul University Cerrahpaşa Faculty of Medicine, Department of Geriatrics, İstanbul, Turkey
}

\begin{abstract}
Hashimoto's encephalopathy is a disease considered to derive from an autoimmune etiology, associated with antithyroid auto-antibodies. Clinical manifestations may include acute or latent conditions. The disease is diagnosed through clinical manifestations, high anti-thyroid auto-antibodies and elimination of other conditions that may also cause encephalopathy. In this report, we present two patients admitted with acute neurological deterioration and diagnosed with Hashimoto's encephalopathy.
\end{abstract}

Keywords: Hashimoto's encephalopathy, seizure, cognitive impairment.

\section{Öz}

Hashimoto ensefalopatisi anti-tiroid otoantikorlarla ilişkili otoimmün etiyolojiye sahip olduğu düşünülen bir hastalıktır. Klinik tablo akut ya da sinsi olarak başlayabilir. Hastalık tanısı, klinik bulgular varlığında, serumda antitiroid otoantikorların yüksek bulunması ve ensefalopatiye neden olabilecek diğer nedenlerin ekarte edilmesiyle konur. Bu yazıda, akut nörolojik defisit ile başvuran ve Hashimoto ensefalopatisi tanısı almış iki olgu sunulmaktadır.

Anahtar Sözcükler: Hashimoto ensefalopatisi, nöbet, kognitif bozulma.

\section{Introduction}

Hashimoto's encephalopathy is a rare disease considered to derive from an autoimmune etiology, associated with anti-thyroid auto-antibodies. The mean age of onset is 44 , and female to male ratio is $4: 1$ (1).

Clinical manifestations may include acute conditions such as cerebral ischemia-like episodes, seizures, psychosis and impaired consciousness or latent conditions such as depression, dementia and cognitive deterioration. Both types may associate with tremor and myoclonus (1,2-4).

Serum TSH (thyroid-stimulating hormone) levels may be normal. Cerebro-spinal fluid (CSF) protein levels are generally elevated without cells. Electroencephalography $(E E G)$ is abnormal in almost every case.

Corresponding Author: Zerrin Yıldııım

Bağcılar Training and Research Hospital, Clinic of Neurology, İstanbul, Turkey

Received: 30.10.2017 Accepted: 04.12.2017
Diffuse deceleration, intermittent and rhythmic delta activity at frontal, triphasic waves or epileptiform anomalies can appear. Neuroimaging is not specific and may be normal. In cranial magnetic resonance imaging (MRI), T2 and FLAIR sequences can present hyperintensity in subcortical white matter or on the line between grey and white matters. The disease responds well to steroid treatment (5).

In this article, we present two cases that had acute clinical manifestations and rapid response to steroid treatment.

\section{Case Report}

Case1. A 46-year-old female patient with no previous complaints applied with weakness and numbness in arms, legs and face with a sudden onset. Her medical history had no remarkable condition. In neurological examination her time orientation was lost and she had a side changing hemiparesis. Cranial MRI showed hyperintensity in left temporal cortex. The patient started to get treatment with pre-diagnosis of ischemic cerebral disease. 
Serum TSH level was $8.788 \mu \mathrm{IU} / \mathrm{mL}$ (0.63-4.82); fT3, $2.84 \mathrm{pg} / \mathrm{mL}$ (2.3-4.2); fT4, $1.07 \mathrm{ng} / \mathrm{dL}$ (0.88-1.72). EEG revealed significant bioelectric disruption in both frontotemporal areas (Figure-1a).The patient was monitored in the intensive care unit due to progressive worsening of consciousness and developing respiratory deficiency. A lumbar puncture was performed with a prediagnosis of encephalitis. In CSF examination there was no cell, protein level was $76.7 \mathrm{mg} / \mathrm{dL}(15-40)$ and the rest of biochemistry was normal. The patient received Acyclovir $30 \mathrm{mg} / \mathrm{kg} /$ day with a pre-diagnosis of atypical viral encephalitis, but did not respond. Mycobacterium tuberculosis, Brucella, Borrelia, HSV types 1-2, CMV, VZV, EBV PCR, VDRL-RPR and ARB were negative.

Case 2. A 52-year-old female patient applied to our hospital with generalized tonic clonic seizure. She had a seizure and got well without treatment one month before admission to our hospital. She had a known hypothyroidism and was using l-thyroxin treatment. Impaired consciousness was found in neurological examination after controlling seizures. Cranial MRI was normal. Serum TSH level was $17.04 \mu \mathrm{IU} / \mathrm{mL}$ (0.63-4.82); fT3, $1.93 \mathrm{pg} / \mathrm{mL}$ (2.0-4.4); fT4, $0.865 \mathrm{ng} / \mathrm{dL}$ (0.93-1.70). EEG revealed mild and diffuse bioelectric disruption in left hemisphere (Figure-1b). Similar to the first patient, there was no cell, protein level was $64.7 \mathrm{mg} / \mathrm{dL}$ (15-40) and the rest of biochemistry was normal in CSF and bacteriological and viral markers were negative. The patient's history of hypothyroidism and repetitive process caused us to think Hashimoto's encephalopathy rapidly.

For the differential diagnosis of limbic encephalitis, malignancy, metabolic encephalopathy and vasculitis NMDA-R, AMPA-R1 Ab, AMPA-R2 Ab, CASPER, Abu LGl1, GAD Ab, CEA, CA 125, CA 19-9, CA 15-3, CA 72 4, lactate, pyruvate, ammonia, lupus anticoagulant, protein $\mathrm{C}$, protein $\mathrm{S}$, ANA, ANCA, p-ANCA, anticardiolipin antibodies, anti-Ro, anti-La, anti-dsDNA were examined for both patients and were negative.

For both patients taking the abnormality in the thyroid function tests into consideration, anti-thyroid antibodies were checked with pre-diagnosis of Hashimoto's encephalopathy. The results were, in orderly, anti-TPO $\mathrm{Ab}:>600 \mathrm{IU} / \mathrm{mL}(0-35)$ anti-thyroglobulin $\mathrm{Ab}: 540.1$ $\mathrm{IU} / \mathrm{mL}(0-115)$ and anti-TPO $\mathrm{Ab}:>600 \mathrm{IU} / \mathrm{mL}$, antithyroglobulin Ab: $475.7 \mathrm{IU} / \mathrm{mL}$. These results supported the diagnosis, so patients started taking methylprednisolon $1 \mathrm{mg} / \mathrm{kg} /$ day. Their clinical conditions started to improve after the first week of treatment and at $15^{\text {th }}$ day of treatment both were conscious and oriented.

Written informed consent was obtained from the two patients for publishing the individual medical records.

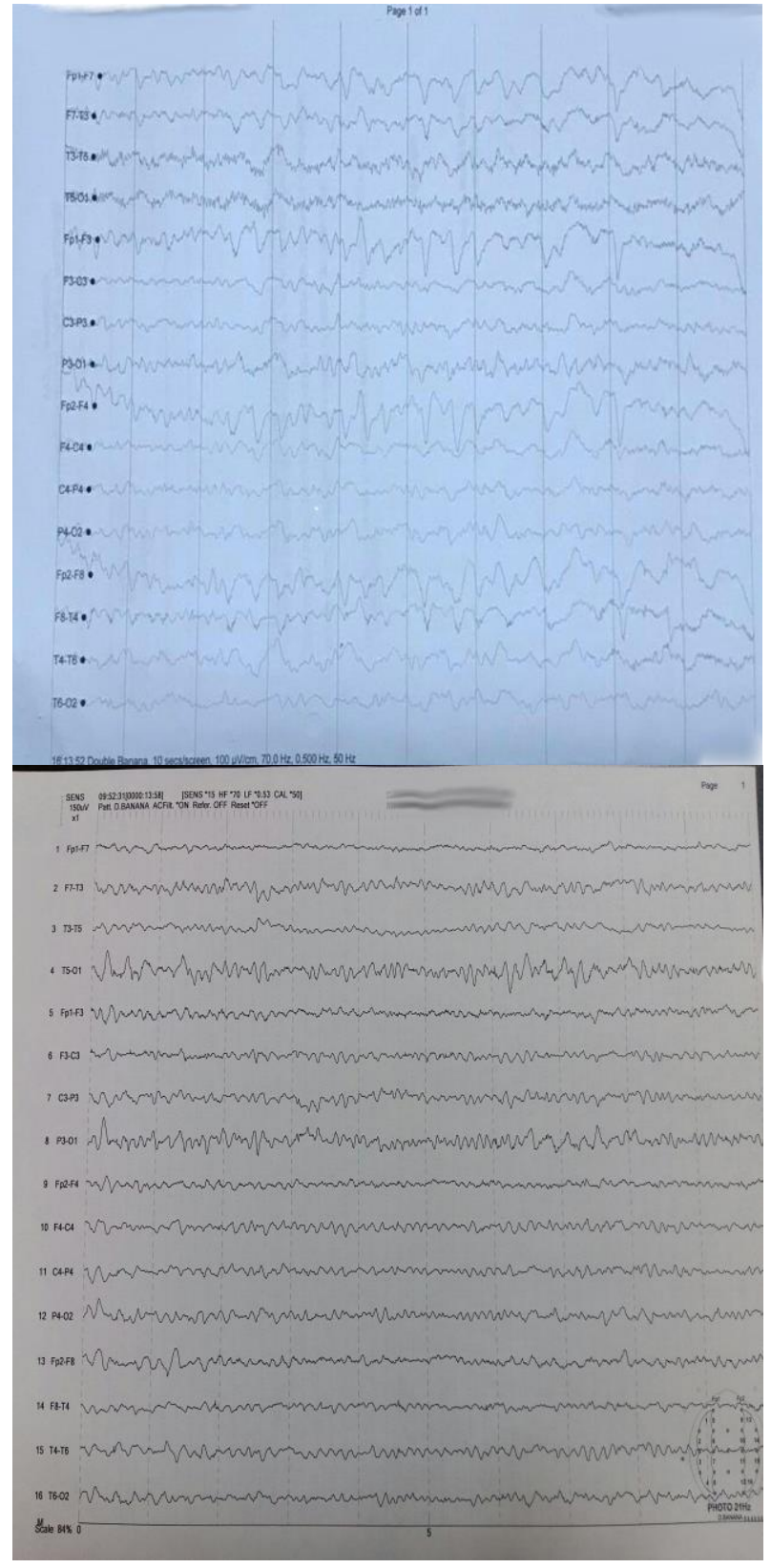

Figure-1. a. EEG of the first patient. Bioelectric disruption in both frontotemporal areas.b. EEG of the second patient. Mild and diffuse bioelectric disruption more apparent in left hemisphere.

\section{Discussion}

Hashimoto's encephalopathy is a disease associated with anti-thyroid auto-antibodies. Non-specifity of the symptoms, imaging and EEG complicates and delays the diagnosis (5). Ruling the other diagnoses out and keeping this particular disease in mind play key roles for diagnosing. Our cases applied with acute neurological conditions and non-specific imaging and EEG findings. Thyroid function tests may be normal. TSH levels of our patients were significantly higher, fT3 and fT4 levels were non-specific.

The disease rapidly responds to steroid treatment. Clinics of our patients showed significant recovery at the 
second week of treatment. This quick response supports our diagnosis.

The disease was diagnosed through clinical manifestations, high anti-thyroid auto-antibodies and elimination of other causes of encephalopathy. Consequently, Hashimoto's encephalopathy should be considered for the patients with stroke-like episodes, seizures, sensory loss, and dementia even though the thyroid function tests are in normal range. Quick response to steroid treatment is further evidence supporting the diagnosis. Being a disease that is seen in young adult patients, fatal unless diagnosed and reversible if treated with steroids, Hashimoto's encephalopathy is significant to take into consideration.

\section{References}

1. Colakoglu BD, Koca PK, Yener G. Reversible cognitive disorder accompanying Hashimoto thyroiditis. Arch Neuropsychiatry 2008;45(1):19-20.

2. De Holanda NC, de Lima DD, Cavalcanti TB, Lucena CS, Bandeira F. Hashimoto's encephalopathy: Systematic review of the literarute and an additional case. J Neuropsychiatry Clin Neurosci 2011;23(4):384-90.

3. Salazar R, Mehta C, Zaher N, Miller D. Opsoclonus as a manifestation of Hashimoto's encephalopathy. Clin Neurosci 2012;19(10):1465-6.

4. Lee MJ, Lee HS, Hwang JS, Jung DE. A case of Hashimoto's encephalopathy presenting with seizures and psychosis. Korean J Pediatr 2012;55(3):111-3.

5. Castillo P, Woodruff B, Caselli R, et al. Steroid-responsive encephalopathy associated with autoimmune thyroiditis. Arch Neurol 2006;63(2):197-202 